\title{
Stress and Anxiety in the Maternal During the COVID-19 Pandemic
}

\author{
Lenny Irmawaty Sirait ${ }^{1}$, Yafi Sabila Rosyad ${ }^{2}$, Ernauli Meliyana ${ }^{3}$, Dyah Maria Ulfah ${ }^{4}$, \\ Cipta Pramana ${ }^{5}$ \\ ${ }^{1}$ The Assistant Professor at The Program Studi Kebidanan (D3) STIKes Medistra Indonesia, Jakarta Indonesia, \\ ${ }^{2}$ The Lecturer at The STIKes Yogyakarta Indonesia, ${ }^{3}$ The Lecturer at The Program Studi Keperawatan (Ners) \\ STIKes Medistra Indonesia, Jakarta, ${ }^{4}$ The Lecturer at The STIKes Bani Saleh, Bekasi Indonesia, ${ }^{5}$ The Lecturer \\ at The STIKES Guna Bangsa Yogyakarta, Indonesia, ${ }^{5}$ The Researcherat The Medical Faculty Tarumanagara \\ University Jakarta Indonesia
}

\begin{abstract}
Background \& Aim: Decreased immunity in pregnant and birthing women makes this population vulnerable, both physiologically and psychologically. The global pandemic of acute respiratory syndrome caused by coronavirus 2 (SARS-CoV2), which is the new virus that causes coronavirus disease 2019 (COVID-19), increases the risk of psychological distress including stress and anxiety that can impact pregnancy and/or childbirth disorders. The research objective was to determine the conditions of stress and anxiety in the maternal during the COVID-19 pandemic
\end{abstract}

Methods \& Materials: This study used a descriptive survey method on a sample of pregnant women and women giving birth by purposive sampling, namely those who visited the Independent Practice Midwife (BPM) clinic in Bekasi City from April to July 2020 totaling 58 people. Data were collected using the DASS-21 questionnaire which was packaged in a google form and distributed online via the social media WhatsApp (WA). The data collected was then analyzed descriptively to be presented as a result of the study.

Results: Most of the respondents were 20-35 years old, had secondary education and most of them had primiparous parity. Most of the respondents' stress conditions were within normal limits, but there was also mild $(15,52 \%)$ to moderate stress $(13,79 \%)$. Most of the respondents' anxiety was within normal limits, however, there was also mild $(13,79 \%)$, moderate $(13,79 \%)$, severe $(8,62 \%)$ to very severe anxiety $(1,72 \%)$.

Conclusion: Stress and anxiety occurred in respondents as a psychological response during the COVID-19 pandemic; so that active management is needed to prevent the effects of stress and prolonged anxiety.

Keywords: Stress, Anxiety, COVID-19, Maternal, Immunity

\section{Introduction}

The physiological and psychological changes that occur during pregnancy and childbirth lead to an increased risk of perinatal stress and anxiety. ${ }^{1}$ Anxiety is defined as feeling worried, nervous, or anxious about something whose result is uncertain and is a condition that affects depressiona. ${ }^{2}$ Feelings of worry are caused by negative thoughts which will cause negative feelings and ultimately cause stress. ${ }^{3}$
Decreased immunity in pregnant and childbirth women makes this population vulnerable, both physiologically ${ }^{4}$ and psychologically and there is an increased risk of psychological distress including stress, anxiety, and depression, ${ }^{5-7}$ which can increase motherhood and morbidity. neonatal. Uguz, et al. It is stated that $18.2 \%$ of pregnant women experience mood disorders or anxiety during pregnancy. Generalized anxiety disorder, obsessive-compulsive disorder, panic disorder and comorbidity in anxiety disorders are more 
common during pregnancy. ${ }^{8}$ Anxiety and depression occur $13-21 \%$ in the prenatal period and $11-17 \%$ occur in postpartum women. ${ }^{9}$ The incidence of anxiety in pregnant women in Indonesia reaches 373,000,000, where $28.7 \%$ or as many as $107,000,000$ pregnant women experience anxiety before childbirth. Perinatal anxiety is often associated with a history of mental health, marital disputes, stressful living environment, lack of social support, low socioeconomic status, and general fears resulting from a poor pregnancy diagnosis such as miscarriage, preterm labor, low birth weight, etc. condition. maternal health is disturbed. ${ }^{10}$

Perinatal stress and anxiety may increase due to the global pandemic an acute respiratory syndrome caused by coronavirus 2 (SARS-CoV2), the new virus that causes coronavirus disease 2019 (COVID-19). ${ }^{11}$ The COVID-19 outbreak was identified in Wuhan (China). the end of 2019 until it became a pandemic declared by the World Health Organization (WHO) on March 11, 2020. This statement almost coincided with the identification of COVID-19 in Indonesia, to be precise on March 2, 2020. ${ }^{12}$ COVID-19 cases continued to increase up to -62 , namely on May 3, 2020, there were 11,192 positive cases, 1,876 cases recovered, and 845 cases died. As of December 23, 2020, COVID-19 cases in Indonesia have reached 685,639 people, recovered 558,703 people and died 20,408 people. ${ }^{13}$

The rapid spread of SARS-CoV-2 can stress everyone, especially pregnant women, as a vulnerable and high-risk group during the COVID-19 pandemic. ${ }^{14}$ The COVID-19 pandemic in pregnant women and infants can have detrimental impacts both in the short and long term ${ }^{15}$ ranging from mental illness to medical. This condition puts pregnant women and their babies at high risk of dying and their health declining. It has previously been reported that women exposed to the $1918 \mathrm{flu}$ pandemic (commonly known as the Spanish flu) while pregnant exhibited higher rates of preterm birth in the short term. Meanwhile, long-term flu pandemics have also been reported while in the womb to have a higher risk of developing schizophrenia, diabetes, coronary heart disease, or cancer throughout life. ${ }^{16}$
Pregnant women are at a higher risk of developing severe disease from COVID-19 and death than people who are not pregnant. Also, pregnant women with COVID-19 are at a higher risk of experiencing preterm birth (giving birth $<37$ weeks). ${ }^{16,17}$ Maternal stress and anxiety during the COVID-19 pandemic was also triggered by the transition to the application of new protocols in the implementation of antenatal care and also before delivery, you must screen for COVID-19 to anticipate transmission, ${ }^{18}$ while It was reported that the system capacity health is still low, including health infrastructure and facilities as well as Health Human Resources (HRK) in DKI Jakarta including other buffer areas around it, namely Bogor, Depok, Tangerang, South Tangerang and Bekasi (Bodetabek). ${ }^{19}$

This research was conducted to determine the psychological response of pregnant women and women giving birth during the COVID-19 pandemic and its impact on perinatal stress and anxiety.

\section{Material and Method}

This research was conducted using a descriptive survey method, which is to determine the psychological response of pregnant women and women giving birth during the COVID-19 pandemic. The research subjects were pregnant women and women giving birth who visited the Independent Practice Midwife (BPM) clinic in Bekasi City from April to July 2020. This sample was taken by purposive sampling due to limitations in the pan-for-COVID-19 period. The research was carried out after obtaining approval from the Health Research Ethics Commission No.614 / KEPK / STIKES-NHM / $\mathrm{EC} / \mathrm{IV} / 2020$.

The data were collected using of a survey using a questionnaire containing questions about "Depression, Anxiety and Stress Scale - 21 Items (DASS-21)" which is packaged in the google form and distributed online via WhatsApp (WA) social media. 58 subjects gave responses from April to July 2020 and were then analyzed descriptively to be presented as research results.

\section{Results and Discussion}

The results showed that based on the characteristics 
of the majority of the respondents aged 20-35 years, had secondary education and had primiparous parity (Table 1).

\begin{tabular}{|c|c|c|}
\hline Characteristics & $\mathrm{n}=(\mathbf{5 8})$ & $\%$ \\
\hline \multicolumn{3}{|l|}{ Age (Years) } \\
\hline$<20$ & 1 & 1,72 \\
\hline $20-35$ & 54 & 93,10 \\
\hline$>35$ & 3 & 5,17 \\
\hline \multicolumn{3}{|l|}{ Education } \\
\hline Basic & 5 & 8,62 \\
\hline Intermediate & 29 & 50 \\
\hline High & 24 & 41,38 \\
\hline \multicolumn{3}{|l|}{ Parity } \\
\hline Nullipara & 15 & 25,86 \\
\hline Primipara & 27 & 46,55 \\
\hline Multiparous & 16 & 27,59 \\
\hline
\end{tabular}

The stress response experienced by respondents was mostly within normal limits, but there were also mild to moderate stresses (Table 2).

Table 2. Stress Response of Pregnant Women and Maternity During the COVID-19 Pandemic

\begin{tabular}{|c|c|c|}
\hline Stress & $\mathrm{n}=(58)$ & $\%$ \\
\hline Normal & 41 & 70,69 \\
\hline Light & 9 & 15,52 \\
\hline Moderate & 8 & 0 \\
\hline Weight & 0 & 0 \\
\hline Very heavy & 0 & 0 \\
\hline
\end{tabular}


The anxiety response shows that most respondents are within normal limits.However, there were also respondents with mild, moderate, severe, and very severe anxiety (Table 3).

Table 3. Anxiety Responses of Pregnant Women and Maternity During the COVID-19 Pandemic

\begin{tabular}{|c|c|c|}
\hline Anxiety & $\mathbf{n}=\mathbf{( 5 8 )}$ & $\mathbf{\%}$ \\
\hline Normal & 36 & 62,07 \\
\hline Light & 8 & 13,79 \\
\hline Moderate & 8 & 13,79 \\
\hline Weight & 5 & 8,62 \\
\hline Very heavy & 1 & 1,72 \\
\hline
\end{tabular}

Every life problem that befalls a person is called a Psychosocial Stressor which can result in malfunctioning of the body's organs. This body (physical) reaction is called stress. Stress is the body's non-specific response to its demands. When the demands on the body are excessive, it is called distress. Stress is a trigger factor, cause and effect of a disorder or disease. Stress in life is something that cannot be avoided. The problem is how humans live with stress without having to experience distress. ${ }^{20}$

Psychosocial stressors include disturbed interpersonal relationships, work, and the environment. ${ }^{21}$ This disorder becomes a source of stress which eventually leads to depression and anxiety. ${ }^{20}$ During the COVID-19 pandemic, there were restrictions to limit the spread of SARS-CoV-2. (22) The COVID-19 pandemic is a massive global health crisis requiring large-scale behavior change that places a significant psychological burden on individuals. ${ }^{23}$ Governments around the world are imposing behavioral adjustments (such as lockdowns, social distancing restrictions, and restrictions mobility Social distancing is an important approach that can have adverse mental health effects Humans are instinctively social and tend to converge as a mechanism for coping with high levels of stress and a way to increase resilience. ${ }^{24}$ Isolation and limited movement can result in pregnant women experiencing a lack of social support from friends, relatives and partners, economics, jobs long-distance and potentially living in a crowded house. Further stressors are related to social distancing and anxiety about losing their jobs (layoffs), etc. ${ }^{25}$

An online survey on mental health status assessed using DASS-21 by Wang et al involving 1,210 respondents from 194 cities in China stated that there were $28.8 \%$ of respondents with moderate to severe anxiety and $8.1 \%$ with moderate to severe stress. ${ }^{26}$ Another study was conducted on 318 women using the Patient Health Questionnaire - Two Item (PHQ-2) screening method. Of all the women who tested positive for SARS-CoV-2, one in eight women (12.5\%) reported feelings of sadness, depression, or hopelessness that had been felt for at least half a day in the past 2 weeks. A total of 310 out of 318 women (97.5\%) tested negative for SARS-CoV-2 and had no symptoms. A total of 166 women (53.5\%) of whom were multiparous and $34.4 \%$ answered that COVID-19 causes additional fear or anxiety in the postpartum period compared to previous deliveries. Meanwhile, $100 \%$ of the nulliparous women stated that fear or anxiety about COVID-19 did not affect their ability to care for their babies or their ability to recover from childbirth. ${ }^{27}$

After, it was announced that the coronavirus was a pandemic, at the same time pregnant women had significantly higher rates of depression with symptoms than before it was announced. Pregnant women are more likely to have thoughts of hurting themselves $\left(\mathrm{P}^{1 / 4.005)}\right.$. Depression rates were positively related to the number of newly confirmed coronavirus cases in 2019 $\left(\mathrm{P}^{1} / 4.003\right)$, suspected infections $\left(\mathrm{P}^{1 / 4.004}\right)$, and deaths per day $\left(\mathrm{P}^{1 / 4.001)}\right.$. Pregnant women who were underweight before becoming pregnant, primiparous, younger than 35 years of age, working full-time, in middle-income categories, and having adequate housing are at higher risk for developing symptoms of depression and anxiety during the outbreak. ${ }^{14}$

A decrease in partial immunity due to pregnancy makes pregnant women more susceptible to viral infections. Therefore, the COVID-19 pandemic can 
have serious consequences for pregnant women. ${ }^{28}$ The welfare of the fetus is one of the main concerns of mothers. Although vertical transmission has not been confirmed with concrete evidence, maternal feelings of concern remain about the risk,or infection in the infant in the peripartum period. It is necessary to increase medical observation during pregnancy, but this is difficult during a pandemic and difficulties in accessing professional medical assistance can be a source of anxiety for pregnant women. In addition, the feeling of insecurity experienced by pregnant women is the risk of being exposed to the corona virus when accessing medical facilities. ${ }^{29}$ Besides, since school distractions from home make the presence of children 24 hours at home is a source of additional stress for pregnant women and giving birth because the additional time which should be given to caring for children and families, lack of physical/outdoor activity, and the need to provide homeschooling. Financial problems and new duties related to family care have the potential to create misunderstandings among family members. Support from partners has a significant effect on maternal wellbeing and therefore single mothers will be more prone to anxiety. ${ }^{30}$ The COVID-19 pandemic has also heightened fear and uncertainty. This can lead to negative social behavior. Experiences of isolation, fear of being trapped, and rumors spreading on social media, ${ }^{31}$ Other aspects are also severely affected, such as family gatherings, participation in holidays, religious celebrations, births, funerals, etc. can cause anxiety and increased social anxiety. ${ }^{25}$ Another important social aspect is the fear of guilt, guilt and stigmatization associated with being infected with COVID-19. An infected person can be subject to discrimination. ${ }^{32}$

Individuals who experience stress will disrupt their life cycle. There are discomfort and tension that causes difficulty which results in anxiety and causes the nervous system to become less controlled. Several things cause stress in individuals, including feeling anxious about the results achieved, unbalanced activities, pressure from oneself, a condition of uncertainty, feelings of anxiety, feelings of guilt, emotional thirst, and socioeconomic conditions. Stress causes anxiety (anxiety) and the nervous system becomes less controlled. The nerve center of the brain activates the sympathetic nerves, thereby encouraging the secretion of adrenaline and cortisol, which in turn mobilize other hormones. Individuals under stress conditions, physiologically, will encourage the release of sugar from the liver and breakdown of body fat, and increase the fat content in the blood. This condition results in increased blood pressure and more blood diverted from the digestive system into the muscles, causing stomach acid production to increase and the stomach to feel bloated and nauseous. Therefore, prolonged stress will have an impact on depression which in turn also has an impact on human physiological functions, including kidney failure and stroke. ${ }^{3}$

During the COVID-19 pandemic, there were restrictions including maternal and neonatal health services and this made pregnant women reluctant to go to Puskesmas or other health service facilities for fear of being infected. ${ }^{33}$ The COVID-19 pandemic requires the application of new protocols (guidelines) for mothers pregnant and about to give birth, namely minimizing contact with other people who can cause transmission of the coronavirus. Centers for Disease Control and Prevention (CDC) states that pregnant women continue to do antenatal care but consult through providers and to prevent transmission of the virus to babies, doctors or midwives/nurses who will assist in childbirth, before delivery, a SARS-CoV-2 RT-PCR screening is performed. Pregnant women who are suspected or confirmed are temporarily separated from their babies, but breastfeeding is still given, and the breastfeeding process is chained by the caregiver. ${ }^{18}$

\section{Conclusion}

In this study, stress and anxiety occurred in pregnant women and women giving birth as a psychological response during the COVID-19 pandemic. Individual manifestations of the COVID-19 pandemic vary as well as during the perinatal period, many factors affect the psychological stress that occurs. The severity of stress and anxiety that occurs during pregnancy and childbirth all require treatment because they can harm the health of mothers and babies both in the short term and in the long term. Active management is needed to prevent the effects of stress and prolonged anxiety, including by 
carrying out COVID-19 education, training in relaxation techniques and assisting pregnant women/mothers in accordance with established protocols.

Acknowledgment: Thank you to the owner of the Independent Practice Midwife (BPM) clinic in Bekasi City for allowing the research

\section{Funding: Nil}

Conflict of Interest: The study has no conflict of interest.

Ethical Clearance: It is taken from the Health Research Ethics Commission No.614 / KEPK / STIKESNHM / EC / IV / 2020.

\section{References}

1. Chen H, Selix N, Nosek M. Since January 2020 Elsevier has created a COVID-19 resource centre with free information in English and Mandarin on the novel coronavirus COVID- 19 . The COVID-19 resource centre is hosted on Elsevier Connect , the company' $\mathrm{s}$ public news and information . 2020;(January).

2. Taku-Kemal Sasaki, Aya Yoshida KK. Attitudes about the 2009 H1N1 influenza pandemic among pregnant Japanese women and the use of the Japanese municipality as a source of information. Southeast Asian J Trop Med Public Heal [Internet]. 2013;3(44):388-99. Available from: https:// pubmed.ncbi.nlm.nih.gov/24050070/

3. Sukadiyanto. Stress dan Cara mengatasinya. Cakrawala Pendidik. 2010;29(1):55-66.

4. Robinson DP, Klein SL. Pregnancy and pregnancyassociated hormones alter immune responses and disease pathogenesis. 2012;

5. Melville JL, Gavin A, Fan M. Depressive Disorders During Pregnancy Prevalence and Risk Factors in a Large Urban Sample. Obstet Gynecol. 2010;116(5):1064-70.

6. Organization WH. Mental Health and Substance Use [Internet]. 2020. Available from: https://www. who.int/teams/mental-health-and-substance-use/ maternal-mental-health

7. C. Rubertsson, J. Hellström MC. Anxiety in early pregnancy: prevalence and contributing factors. Arch Womens Ment Health. 2014;17:221-228.
8. Uguz FESAGBK. Prevalence of mood and anxiety disorders during pregnancy: A case-control study with a large sample size. Psychiatry Res [Internet]. 2019;272:316-8. Available from: https:// www.sciencedirect.com/science/article/abs/pii/ S0165178118317475

9. Dennis C, Falah-hassani K, Shiri R. Prevalence of antenatal and postnatal anxiety: systematic review and meta-analysis. $\mathrm{Br} \mathrm{J}$ Psychiatry. 2017;(210):315-23.

10. Fairbrother N, Young AH, Janssen P, Antony MM, Tucker E. Depression and anxiety during the perinatal period. BMC Psychiatry [Internet]. 2015;15(1):1-9. Available from: http://dx.doi. org/10.1186/s12888-015-0526-6

11. Corbett GA, Milne SJ, Hehir MP, Lindow SW, O'connell MP. Health Anxiety and Behavioural Changes of Pregnant Women Durıng the Covid-19 Pandemic. Eur J Obstet Gynecol Reprod Biol. 2020;249(January):96-7.

12. Organization WH. Coronavirus disease (COVID-19) pandemic [Internet]. [Internet]. 2020. Available from: https://www.who.int/emergencies/ disease $\% 0$ As/novel-coronavirus-2019

13. ISTA/QQ/DDL. Sebanyak 558.703 Pasien Sembuh Dari Covid-19 [Internet]. [Internet]. 2020. Available from: https://covid19.go.id/p/berita/sebanyak\%0A558703-pasien-sembuh-dari-covid-19

14. Peters A, Rospleszcz S, Greiser KH, Dallavalle M, Berger K. The Impact of the COVID-19 Pandemic on Self-Reported Health. Dtsch Arztebl Int. 2020;117(50):861-7.

15. Kotabagi P, Fortune L, Essien S, Nauta M, Yoong W. Anxiety and depression levels among pregnant women with COVID-19. Acta Obstet Gynecol Scand. 2020;99(7):953-4.

16. Caparros-Gonzalez RA, Ganho-Ávila A, TorreLuque A de la. The COVID-19 Pandemic Can Impact Perinatal Mental Health and the Health of the Offspring. Behav Sci (Basel). 2020;10(11):162.

17. Pradana AA, Casman C, Nur'aini N. Pengaruh Kebijakan Social Distancing pada Wabah COVID-19 terhadap Kelompok Rentan di Indonesia. J Kebijak Kesehat Indones JKKI [Internet]. 2020;9(2):61-7. Available from: https:// jurnal.ugm.ac.id/jkki/article/view/55575

18. CDC. Pregnancy, Breastfeeding, and Caring for Newborns. 2020. 
19. Saputra H, Salma N. Dampak PSBB dan PSBB Transisi di DKI Jakarta dalam Pengendalian COVID-19. Media Kesehat Masy Indones. 2020;16(3):282-92.

20. Jamil J. Sebab Dan Akibat Stres, Depresi Dan Kecemasan Serta Penanggulangannya. Al Amin J Kaji Ilmu dan Budaya Islam. 2019;1(1):123-38.

21. Mizrak Sahin B, Kabakci EN. The experiences of pregnant women during the COVID-19 pandemic in Turkey: A qualitative study. Women and Birth. 2020;

22. Aghababaei S, Bashirian S, Soltanian A, Refaei M, Omidi T, Ghelichkhani S, et al. Perceived risk and protective behaviors regarding COVID-19 among Iranian pregnant women. Middle East Fertil Soc J. 2020 Dec 1;25(1).

23. Bavel JJV, Baicker K, Boggio PS, Capraro V, Cichocka A, Cikara M, et al. Using social and behavioural science to support COVID-19 pandemic response. Nat Hum Behav [Internet]. 2020;4(5):460-71. Available from: http://dx.doi. org/10.1038/s41562-020-0884-Z

24. Chivers BR, Garad RM, Boyle JA, Skouteris $\mathrm{H}$, Teede HJ, Cheryce ; et al. Perinatal Distress During COVID-19: Thematic Analysis of an Online Parenting Forum. J Med INTERNET Res [Internet]. 2020 [cited 2020 Dec 30];9(22). Available from: http://www.jmir.org/2020/9/e22002/

25. Wall V, Premji SS, Letourneau N, Mccaffrey G, Charles Nyanza E. Factors associated with pregnancy-related anxiety in Tanzanian women: a cross sectional study. BMJ Open [Internet]. 2018 [cited 2020 Dec 31];8:20056. Available from: http://bmjopen.bmj.com/

26. Wang $\mathrm{C}$, Pan $\mathrm{R}$, Wan $\mathrm{X}$, Tan $\mathrm{Y}, \mathrm{Xu} \mathrm{L}$, Ho CS, et al. Immediate Psychological Responses and Associated Factors during the Initial Stage of the 2019 Coronavirus Disease (COVID-19) Epidemic among the General Population in China. Int $\mathrm{J}$ Environ Res Public Heal [Internet]. 2020 [cited 2020 Dec 30];17:1729. Available from: www. mdpi.com/journal/ijerph

27. Tantona MD. Jurnal Penelitian Perawat Profesional. J Penelit Perawat Prof [Internet]. 2019;1(November):89-94. Available from: http:// jurnal.globalhealthsciencegroup.com/index.php/ JPPP/article/download/83/65

28. Brooks SK, Weston D, Greenberg N. Psychological impact of infectious disease outbreaks on pregnant women: rapid evidence review. Vol. 189, Public Health. Elsevier B.V.; 2020. p. 26-36.

29. Kajdy A, Feduniw S, Ajdacka U, Modzelewski J, Baranowska B, Sys D, et al. Risk factors for anxiety and depression among pregnant women during the COVID-19 pandemic: A web-based cross-sectional survey. Medicine (Baltimore). 2020;99(30):e21279.

30. Xiuxiu Ding, Leijing Mao, Xing Ge, Shaojun $\mathrm{Xu}$, Weijun Pan, Shuangqin Yan, Kun Huang FT. Course and risk factors of maternal pregnancyrelated anxiety across pregnancy in Ma' anshan city. Wei Sheng Yan Jiu [Internet]. 2015;44(3):371-5. Available from: https://pubmed.ncbi.nlm.nih. gov/26137612/

31. Usher K, Durkin J, Bhullar N. The COVID-19 pandemic and mental health impacts. Int J Ment Health Nurs. 2020;29(3):315-8.

32. Burdorf A, Porru F, Rugulies R. The COVID-19 (Coronavirus) pandemic: Consequences for occupational health. Scand J Work Environ Heal. 2020;46(3):229-30.

33. Veftisia V. D. Prenatal Yoga dalam Mengurangi Tingkat Kecemasan dan Stress Dimasa Pandemi Covid-19. Call Pap Semin Nas Kebidanan [Internet]. 2020;1 No. 1:112-20. Available from: http://jurnal. unw.ac.id:1254/index.php/semnasbidan/article/ view/652/477 